\title{
Targeted Drugs as Maintenance Therapy after Autologous Stem Cell Transplantation in Patients with Mantle Cell Lymphoma
}

\author{
Fengting Yan ${ }^{1,2}$, Ajay K. Gopal ${ }^{1,2}$ and Solomon A. Graf ${ }^{1,2,3, *}$ \\ 1 Department of Medicine, University of Washington, Seattle, WA 98195, USA; yfengtin@fredhutch.org (F.Y.); \\ agopal@uw.edu (A.K.G.) \\ 2 Fred Hutchinson Cancer Research Center, Seattle, WA 98109, USA \\ 3 Veterans Affairs Puget Sound Health Care System, Seattle, WA 98108, USA \\ * Correspondence: grafsa@uw.edu; Tel.: +01-206-277-4757
}

Academic Editor: Luciano J. Costa

Received: 27 January 2017; Accepted: 8 March 2017; Published: 10 March 2017

\begin{abstract}
The treatment landscape for mantle cell lymphoma (MCL) is rapidly evolving toward the incorporation of novel and biologically targeted pharmaceuticals with improved disease activity and gentler toxicity profiles compared with conventional chemotherapeutics. Upfront intensive treatment of MCL includes autologous stem cell transplantation (SCT) consolidation aimed at deepening and lengthening disease remission, but subsequent relapse occurs. Maintenance therapy after autologous SCT in patients with MCL in remission features lower-intensity treatments given over extended periods to improve disease outcomes. Targeted drugs are a natural fit for this space, and are the focus of considerable clinical investigation. This review summarizes recent advances in the field and their potential impact on treatment practices for MCL.
\end{abstract}

Keywords: stem cell transplantation; mantle cell lymphoma; maintenance therapy

\section{Introduction}

Mantle cell lymphoma (MCL) is an uncommon and heterogeneous subtype of B-cell non-Hodgkin lymphoma (B-NHL). It arises from antigen-naïve B-cells that proliferate in the mantle zone of lymph node germinal centers, and typically presents in an advanced stage, involving lymph nodes and extranodal sites including the gastrointestinal tract. MCL cells are small-to-intermediate sized B-cells that usually overexpress cyclin D1 due to $t(11 ; 14)$ chromosomal translocation [1]. Though B-NHLs are generally classified as either aggressive or indolent-a distinction that informs their natural history and treatment goals-MCL straddles this division. With important exceptions, MCL behaves clinically aggressively; however, like other indolent B-NHLs it is generally considered incurable and treatments are given to palliate symptoms and prolong survival.

Upfront intensive treatment for MCL aims to achieve deep—and consequently, long-term—remissions. After important advances over the past two decades, contemporary regimens include the monoclonal antibody rituximab and high-dose cytarabine combined with multi-agent chemotherapy backbones such as cyclophosphamide, doxorubicin, vincristine, and prednisone (CHOP) [2]. For younger, fit patients that achieve remission with chemoimmunotherapy, consolidation therapy is recommended. This consists of myeloablative high-dose chemo- and/or radiation-therapy (HDT) requiring rescue of the bone marrow stem cell compartment with autologous stem cell transplantation (SCT). Median time to treatment failure and disease relapse using this approach may exceed 7 years [3,4]. Disease relapse is nevertheless inevitable, and is often characterized by more treatment-resistance; therefore, improvement in standard therapies is needed. 
Maintenance therapy-herein defined as relatively low intensity treatment given for extended periods to patients in remission-has received considerable interest in the post-autologous SCT setting for MCL. Maintenance therapy is well-established in other oncological settings, including patients with MCL who receive upfront rituximabCHOP (R-CHOP) without autologous SCT consolidation [5]. As a general rule, maintenance therapy should improve disease-specific outcomes while minimizing toxicities, including physical, financial, and logistical. A growing number of novel biologically-targeted therapies are profoundly altering the landscape of MCL treatment options in both first-line and relapsed settings [6,7]. These agents act through a variety of mechanisms, and possess unique and often limited toxicity profiles; as such, they make attractive candidates for post-autologous SCT maintenance therapy. This review examines the role of targeted therapies to improve outcomes after autologous SCT for MCL.

\section{Autologous Stem Cell Transplantation for Mantle Cell Lymphoma}

While its benefit in contemporary treatment algorithms is not established by randomized phase III data, HDT and autologous SCT consolidation is widely accepted as the optimal therapy for fit patients with MCL in remission. It is reserved for patients younger than 65-70 years old, though no strict chronologic age limit exists. As MCL incidence increases with age, approximately half of newly diagnosed patients may prove eligible for high-intensity treatment. The approach is supported by several studies showing favorable outcomes [8-12]. HDT and autologous SCT carries risk of treatment-related mortality on the order of approximately $1 \%-5 \%$, depending on clinical variables, as well as long-term morbidity including an increased risk for secondary malignancies. The assumed superiority of this strategy must therefore be continually re-evaluated in this era of ever-expanding treatment options for MCL. For now, it remains the standard of care and efforts are ongoing to improve its safety and efficacy.

\subsection{Minimal Residual Disease and Pre-Emptive Treatment}

Minimal residual disease (MRD) refers to detectable MCL cells in peripheral blood or bone marrow using highly sensitive methodologies, including multi-parametric flow cytometry or real-time quantitative polymerase chain reaction [13]. In patients who achieve clinical complete remission according to standard criteria (diagnostic fluorodeoxyglucose-positron emission tomography (PET)/computed tomography (FDG-PET/CT) and morphologic evaluation of the bone marrow), assessment of MRD provides additional prognostic risk stratification [3,14-16]. MRD assessment has been used by some to guide pre-emptive therapy; e.g., with rituximab after standard treatment, including autologous SCT consolidation [17,18]. However, MRD measurement to date remains non-standardized, and as such, is not commonly used to guide treatment selection outside of clinical protocols. At present, for patients with MCL in remission after autologous SCT, administration of maintenance therapy is the key treatment decision faced by their clinical team.

\subsection{Maintenance Therapy}

Maintenance therapy is a well-established approach to postponing disease progression in patients with indolent B-NHL after first-line multi-agent chemoimmunotherapy [19-23]. In addition, maintenance rituximab (MR) given every 2 months to patients with MCL in remission after induction R-CHOP without HDT and autologous SCT consolidation results in improved progression-free and overall survival compared with interferon alpha [5]. MR after induction with other lower-intensity regimens-such as the commonly-used bendamustine plus rituximab (BR) combination-has shown no clear survival benefit to date [24]. Further maturation of these data is awaited, however, and the strategy continues to be quite routinely implemented in practice. However, maintenance therapy in B-NHL can be a double-edged sword, as attempts at improving outcomes must be weighed against toxicities. In the post-autologous SCT space, toxicities can be magnified: physiologic reserve is 
compromised, leading to more immediate and severe drug toxicities, and financial and social support resources are often already strained.

\section{Targeted Maintenance Therapies after Autologous Stem Cell Transplantation for Mantle Cell Lymphoma}

\subsection{Anti-CD20 Monoclonal Antibodies}

MCL is characterized by the expression of the B-cell markers, including CD20-a surface B-cell antigen that regulates cell cycle initiation. Rituximab-a mouse/human chimeric IgG1-K monoclonal antibody-targets CD20 and depletes B-cells through the activation of complement-dependent and antibody-dependent pathways. Rituximab is labeled by the Food and Drug Administration (FDA) to treat a variety of diseases, including B-NHL, chronic lymphocytic leukemia, and certain autoimmune conditions (e.g., rheumatoid arthritis). Rituximab added to $\mathrm{CHOP}$ improves response rate and time to treatment failure in newly-diagnosed MCL [25], and anti-CD20 antibody therapy is a component of most MCL treatment regimens today.

Rituximab monotherapy as maintenance is conceptually attractive due to a favorable side effect profile and pharmacokinetics that permit relatively infrequent dosing. Several small non-comparative studies suggested the value of maintenance rituximab (MR) after autologous SCT in patients with MCL [26-28]. A single-center retrospective analysis of 72 patients by Dietrich et al. reported an improvement in progression-free survival (PFS) but not in overall survival (OS) in the 22 patients that received MR administered at $375 \mathrm{mg} / \mathrm{m}^{2}$ every 3 months for 2 years (Table 1) [29]. In a cohort of 157 patients with MCL treated with HDT and autologous SCT consolidation at the Fred Hutchinson Cancer Research Center in Seattle, 50 were given post-transplant MR, and follow-up data was available for a median of 5 years [30]. In this analysis, MR was associated with an improvement in PFS (hazard ratio, $\mathrm{HR}=0.44 ; p=0.007)$ and $\mathrm{OS}(\mathrm{HR}=0.46 ; p=0.03)$ after multivariate adjustment. Importantly, $\mathrm{MR}$ was given according to a variety of dosing schedules and times after autologous SCT, resulting in a relatively heterogeneously treated population, potentially enhancing the applicability of the observed results to general practice.

Table 1. Selected studies evaluating maintenance therapy after autologous stem cell transplantation for mantle cell lymphoma.

\begin{tabular}{|c|c|c|c|c|c|}
\hline Reference & $\begin{array}{c}\text { Year } \\
\text { Reported }\end{array}$ & $\begin{array}{l}\text { Post-Autologous SCT } \\
\text { Intervention }\end{array}$ & Study Type & Patients & Key Results of Intervention \\
\hline Dietrich et al. [29] & 2014 & $\begin{array}{l}\text { R every } 3 \text { months } \\
\text { for } 2 \text { years }\end{array}$ & Retrospective & 72 & $\begin{array}{l}\text { PFS (HR 0.23) but not OS improved after } \\
\text { multivariate adjustment }\end{array}$ \\
\hline Graf et al. [30] & 2015 & Variable schedule of $R$ & Retrospective & 157 & $\begin{array}{l}\text { Both PFS (HR 0.44) and OS (HR 0.46) } \\
\text { improved after multivariate adjustment }\end{array}$ \\
\hline Le Gouill et al. [31] & $\begin{array}{c}2016 \\
\text { (abstract) }\end{array}$ & $\begin{array}{l}\text { R every } 2 \text { months } \\
\text { for } 3 \text { years }\end{array}$ & $\begin{array}{l}\text { Randomized } \\
\text { phase III }\end{array}$ & 240 & $\begin{array}{l}\text { Both PFS (HR 0.4) and OS (HR 0.5) } \\
\text { improved }\end{array}$ \\
\hline Kaplan et al. [33] & $\begin{array}{c}2015 \\
\text { (abstract) }\end{array}$ & $\begin{array}{l}2 \text { doses of } \mathrm{R} \text { then } \\
\text { bortezomib }\end{array}$ & $\begin{array}{l}\text { Randomized } \\
\text { phase II }\end{array}$ & 102 & $\begin{array}{l}\text { 5-year PFS of } 72.7 \% \text { improved over } \\
\text { historical control }(51.5 \%) \text { not administered } \\
\text { post autologous SCT bortezomib }\end{array}$ \\
\hline
\end{tabular}

Abbreviations. SCT, stem cell transplantation; PFS, progression free survival; OS, overall survival; HR, hazard ratio; $\mathrm{R}$, rituximab.

The French LyMa study (NCT00921414) is a large randomized phase III study investigating MR after autologous SCT. Induction chemoimmunotherapy consists of four courses of rituximab, 
dexamethasone, high-dose cytarabine, platinum (R-DHAP) followed by HDT and autologous SCT for patients in remission; patients not in remission after R-DHAP could receive additional R-CHOP therapy before HDT and autologous SCT. Two hundred and forty patients completed autologous SCT and were randomized 1:1 to MR, dosed at $375 \mathrm{mg} / \mathrm{m}^{2}$ every 2 months for 3 years, or no MR. The final results of the study presented at the 2016 American Society of Hematology congress showed that patients receiving MR had improved PFS (HR 0.4, $p=0.0007$ ) and OS (HR 0.5, $p=0.0454$ ) [31].

In the post-autologous SCT setting, hematopoeisis is weakened and prolonged cytopenias and secondary hypogammaglobulinemia resulting in impaired immunity are common. Rituximab may contribute to each process, and severe neutropenia has been observed at up to twice the rate $(34 \%$ vs. $18 \%, p=0.04$ ) in patients receiving MR after autologous SCT [30]. Though rituximab-related neutropenia may lead to dose-delays and increase risk for infectious complications, it is typically correctable with myeloid growth factor support and does not appear to result in non-relapse mortality rates. Similarly, recurrent infections associated with hypogammaglobulinemia may be mitigated with periodic intravenous immunoglobulin support [34]. Another concern is the impact (if any) of MR on the efficacy of post-autologous SCT re-vaccination [35]. Further study and elucidation of this potential complication is needed.

Though formal publication of the LyMa study is awaited and may reveal additional considerations about the general applicability of this strategy, MR after autologous SCT appears to confer a survival advantage to patients with MCL. It has therefore been adopted as standard of care in our practice with the caveats that patients are engaged in careful counseling of potential infectious toxicities and financial support is in place; rituximab may cost in excess of 5000 U.S. dollars (USD) per dose, and a standard course of MR according to the LyMa protocol consists of up to 18 doses.

Newer anti-CD20 monoclonal antibodies are rapidly gaining traction in the management of B-NHL. Ofatumumab and obinutuzumab are fully humanized anti-CD20 antibodies that target CD20 epitopes distinct from rituximab's, and have proven efficacy in certain B-NHLs including chronic lymphocytic leukemia and follicular lymphoma [36-39]. Little published data exists on their use in MCL [40,41], but preclinical data is promising [42,43]. While no data are available to recommend their use in the post-autologous SCT maintenance setting, a multicenter phase II LyMa study (NCT02896582) is planned for patients with MCL using obinutuzumab-DHAP induction followed by HDT and autologous SCT consolidation with 3 years of obinutuzumab maintenance then additional obinutuzumab maintenance on demand according to MRD status. This trial anticipates enrollment of 83 patients with primary completion estimated for 2019.

\subsection{Radioimmunotherapy}

Radioimmunotherapy combines the lymphotoxic properties of radiation with specific immunologic targeting. The approach has been quite extensively studied in MCL, including as conditioning therapy prior to autologous SCT in the relapsed or refractory setting and as late intensification after first incomplete remission [10,44,45]. Ibritumomab tiuxetan-a murine monoclonal anti-CD20 antibody joined to a radioactive isotope yttrium-90 with the chelator tiuxetan-is approved for indolent B-NHL in the salvage and consolidation settings. It is expensive, with a single dose potentially costing upwards of 50,000 USD, and relatively unwieldy to use in routine practice due to required coordination with nuclear medicine or radiation oncology teams. Nevertheless, it features a unique mechanism of action and can be delivered safely and efficiently by experienced clinicians.

Mondello et al. performed a retrospective study on ibritumomab tiuxetan administered after autologous SCT in 57 patients with MCL treated in Italy and Austria [32]. All patients were treated with three cycles of R-CHOP then three cycles of R-DHAP induction followed by HDT and autologous SCT. Six to ten weeks after transplant, only the 28 patients at the Italian site received further consolidation with ibritumomab tiuxetan. Rituximab maintenance, consisting of $375 \mathrm{mg} / \mathrm{m}^{2}$ administered every 12 weeks for 2 years, was given to all patients. Intensification of consolidation with ibritumomab tiuxetan was associated with prolonged PFS (not reached versus 7 years, $p=0.001$ ) and OS (not reached 
versus 8.1 years, $p=0.008$ ), and appeared to attenuate the prognostic significance of the Mantle Cell Lymphoma International Prognostic Index (MIPI) score. Ibritumomab tiuxetan was well tolerated, with the key toxicities of grade 3-4 neutropenia in $11 \%$ and grade $3-4$ thrombocytopenia in $18 \%$. As a single consolidation-intensification dose, ibritumomab tiuxetan may ultimately prove valuable as "pre-maintenance" followed by anti-CD20 immunotherapy maintenance, particularly in highest-risk $\mathrm{MCL}$, but further investigation is required.

\subsection{Proteosome Inhibitors}

Bortezomib is a small molecule that reversibly binds and inhibits the $20 \mathrm{~S}$ proteasome, resulting in cellular apoptosis via a variety of mechanisms. In MCL, the activity of bortezomib is primarily attributed to decreased proteasome degradation of inhibitor of $\mathrm{kB}(\mathrm{lkB})$ allowing continued inhibition over NF- $\mathrm{kB}$ pathway activity-a critical element in MCL tumorigenesis [46]. Bortezomib has proven efficacy in MCL both as a single agent and in combination with chemoimmunotherapy backbones: it received FDA approval for relapsed MCL in 2006 and in first-line therapy in 2014 [47-49]. Bortezomib also has promising activity as single-agent maintenance given after induction R-CHOP for MCL, with 65 patients showing an impressive 2-year PFS of $62 \%$ in the single-arm phase II SWOG S0601 study [22].

As maintenance therapy after autologous SCT, bortezomib was evaluated in the CALGB (Alliance) 50403 study [33]. Patients were administered induction therapy with two to three cycles of augmented R-CHOP (increased dose of cyclophosphamide and addition of methotrexate) followed by high-dose stem-cell chemomobilization with cytarabine, etoposide, rituximab, and filgrastim and then HDT and autologous SCT. After two doses of post-transplant rituximab, patients were randomized to bortezomib consolidation $\left(1.3 \mathrm{mg} / \mathrm{m}^{2}\right.$ intravenous infusion on days $1,4,8$, and 11 of a 3-week cycle for four cycles total) or bortezomib maintenance $\left(1.6 \mathrm{mg} / \mathrm{m}^{2}\right.$ intravenous infusion weekly 4 of 8 weeks for 18 months) beginning on approximately day 90 after transplant. One-hundred and fifty-one patients were enrolled, and 118 underwent autologous SCT. Of these, 102 were randomized to bortezomib consolidation or bortezomib maintenance. The 2-year PFS rates in the bortezomib maintenance and bortezomib consolidation arms were similar ( $84 \%$ and $89 \%$, respectively), but bortezomib consolidation was associated with relatively more toxicity. Compared with CALGB 59909 (which consisted of the identical regimen without bortezomib maintenance or consolidation and thus served as an historical control), CALGB 50403 demonstrated improved 5-year PFS rates from time of transplantation $(72.7 \%$ versus $51.5 \%, p=0.0006$ ), suggesting a PFS benefit for post-autologous SCT bortezomib maintenance in MCL [50].

The critical toxicity with prolonged bortezomib use is peripheral neuropathy, which can become severe and long-lasting if not recognized. Prior treatment with neurotoxic chemotherapeutic agents appears to increase the incidence of neuropathy from bortezomib [51]. In CALGB 50403, adverse events-namely neuropathy and cytopenias-associated with bortezomib led to withdrawal from the study in $13 \%$ of patients treated on the maintenance regimen. The maintenance schedule was also notably relatively burdensome from the perspective of time commitment, with a total of approximately 36 infusions administered over the course of the 18 months. Financial toxicity is another important consideration, as a course of four doses of bortezomib may cost between 5000 and 10,000 USD.

Later generations of proteasome inhibitors include carfilzomib, an irreversible inhibitor of the 20S proteasome subunit, and ixazomib, an orally administered and reversible $20 \mathrm{~S}$ proteasome subunit. Each have somewhat less associated neurotoxicity than bortezomib and are established therapies in treating multiple myeloma. Carfilzomib has preclinical data supporting its use in MCL [52], and a phase I study (NCT01926665) is planned evaluating the maximum tolerated dose of 6 months carfilzomib after autologous SCT for MCL and other lymphomas. Ixazomib is currently being tested in a phase I/II study (NCT02632396) post-autologous SCT maintenance, with a single oral dose given on days 1, 8, and 15 of 28 day cycles for up to ten cycles. The results of these trials may provide rationale for further study that ultimately expands post-autologous SCT maintenance options for MCL. 


\subsection{Bruton's Tyrosine Kinase Inhibitor}

Bruton's tyrosine kinase (BTK) is important to B-cell signaling, maturation, and to mantle cell lymphomagenesis through activation of the Ras/RAF/MEk/ERK and NF-кB pathways [53]. Ibrutinib covalently binds BTK, irreversibly inactivating the kinase. The activity of ibrutinib in MCL was established in a phase II trial in 111 patients with relapsed or refractory disease, of whom $67 \%$ responded to ibrutinib monotherapy (21\% complete response rate) [54]. Ibrutinib is FDA approved for use in patients that have received at least one prior therapy. Ibrutinib is a once-daily oral drug with a favorable side effect profile, making it an attractive candidate for maintenance therapy.

NCT02242097 is a single-arm phase II trial of up to 4 years of continuous ibrutinib maintenance therapy after first-line treatment of MCL. Interestingly, eligible induction treatment regimens include both multi-agent chemoimmunotherapies with or without autologous SCT. The TRIANGLE study is a randomized, three-arm, parallel-group, open label, international phase III study with planned accrual of 870 patients being conducted by the European MCL Network. The study involves upfront therapy with six alternating courses of R-CHOP and R-DHAP followed by autologous SCT (control arm A) versus R-CHOP + ibrutinib alternating with R-DHAP followed by autologous SCT and up to 2 years of ibrutinib maintenance (experimental arm A + I) versus R-CHOP + ibrutinib alternating with R-DHAP followed by up to 2 years of ibrutinib maintenance (experimental arm I), with a primary endpoint of failure-free survival. The TRIANGLE study is actively recruiting patients, and its estimated primary completion is for 2021.

Ibrutinib is associated with toxicities including cytopenias, gastrointestinal symptoms, edema, and musculoskeletal symptoms, but these are typically mild [55]. Risk of bleeding seems to be increased with ibrutinib due to off-target effects on platelet function, and concurrent use of vitamin $\mathrm{K}$ antagonist anticoagulation is generally advised against [56]. This can complicate management-particularly as ibrutinib is also associated with an increased risk of atrial fibrillation. Nevertheless, ibrutinib is generally extremely well-tolerated, even in frail individuals. Its potential use in MCL as long-term treatment in the post autologous SCT maintenance setting will certainly have to take its cost into account, which is on the order of 10,000 USD a month.

\subsection{Lenalidomide}

Lenalidomide - an analogue of thalidomide-was FDA approved in 2013 for the treatment of relapsed/refractory MCL based on phase II data showing an overall response rate of $28 \%$ (CR of $8 \%$ ) and median duration of response of 16.6 months in 134 patients with relapsed or refractory disease [57]. Its mechanism of action on lymphoma involves engagement of the unbiquitin ligase cereblon resulting in both immunomodulation of the tumor microenvironment-particularly natural killer cell stimulation-and direct tumor killing [58].

Fondazione Italiana Linfomi is an ongoing randomized phase III study opened in 2010 and that has now completed recruitment (NCT02354313). It is evaluating the role of lenalidomide maintenance after upfront autologous SCT in MCL. The study is designed to randomize 300 subjects to lenalidomide maintenance dosed at 10-15 mg daily on days 1-21 out of every 28 for 2 years versus observation after an induction of three cycles of R-CHOP followed by high-dose cyclophosphamide and two cycles of high dose cytarabine then HDT and autologous SCT consolidation. The primary endpoint is PFS at 30 months after randomization.

Similar to ibrutinib, lenalidomide is a once-daily medication taken orally. However, it is usually associated with more significant toxicities-particularly fatigue and cytopenias requiring dose adjustments or delay. In addition, it increases the risk of arterial and venous thromboembolic events, and concurrent prophylaxis with, for example, a daily aspirin should be administered. Lenalidomide is also associated with a small increased risk of secondary malignancies in patients receiving it for multiple myeloma, though whether that applies to other situations is not known. It is also a high-cost medication. Overall, lenalidomide as maintenance therapy after autologous SCT for MCL may prove 
efficacious, but other options as described above are likely to eclipse it due to its relatively more significant toxicity profile.

\subsection{Combination Treatments}

Various studies are exploring the role of combination therapies for post-autologous SCT maintenance for MCL. These include NCT01267812, a phase II multicenter trial using bortezomib plus rituximab in 36 patients with MCL and NCT00992446, a phase II study of bortezomib and vorinostat, a histone deacetylase inhibitor, in 20 patients with NHL, including MCL. Both studies are active, and recruitment for NCT01267812 is ongoing. NCT01045928 was a phase I/II trial of the combination of lenalidomide with rituximab as maintenance after autologous SCT in patients with B-NHL that was terminated because of toxicity observed in phase I.

\section{Conclusions}

The introduction of targeted therapies has revolutionized the treatment paradigm of MCL. Based on recently presented prospective data from LyMa, post-autologous SCT MR should now be considered standard of care, but requires attention to its potential impact on immune reconstitution and cytopenias. Other agents are under intensive investigation as maintenance after autologous SCT, and will hopefully prove efficacious in their own right, adding options featuring non-overlapping toxicity profiles. Results of these studies are anticipated in the coming years and will likely guide further research efforts, including MRD-stratification of initiation and duration of treatment, biomarker-based selection of therapy, and rational therapeutic sequencing or combinations.

Acknowledgments: Research reported in this publication was supported by the NCI under award number T32CA009515.

Conflicts of Interest: The authors declare no conflict of interest.

\section{References}

1. Swerdlow, S.H.; Campo, E.; Pileri, S.A.; Harris, N.L.; Stein, H.; Siebert, R.; Advani, R.; Ghielmini, M.; Salles, G.A.; Zelenetz, A.D.; et al. The 2016 revision of the world health organization classification of lymphoid neoplasms. Blood 2016, 127, 2375-2390. [CrossRef] [PubMed]

2. Rule, S. Frontline therapy and role of high-dose consolidation in mantle cell lymphoma. Hematol. Am. Soc. Hematol. Educ. Program 2016, 2016, 419-424. [CrossRef] [PubMed]

3. Hermine, O.; Hoster, E.; Walewski, J.; Bosly, A.; Stilgenbauer, S.; Thieblemont, C.; Szymczyk, M.; Bouabdallah, R.; Kneba, M.; Hallek, M.; et al. Addition of high-dose cytarabine to immunochemotherapy before autologous stem-cell transplantation in patients aged 65 years or younger with mantle cell lymphoma (MCL younger): A randomised, open-label, phase 3 trial of the european mantle cell lymphoma network. Lancet 2016, 388, 565-575. [PubMed]

4. Eskelund, C.W.; Kolstad, A.; Jerkeman, M.; Raty, R.; Laurell, A.; Eloranta, S.; Smedby, K.E.; Husby, S.; Pedersen, L.B.; Andersen, N.S.; et al. 15-year follow-up of the second nordic mantle cell lymphoma trial (MCL2): Prolonged remissions without survival plateau. Br. J. Haematol. 2016, 175, 410-418. [CrossRef] [PubMed]

5. Kluin-Nelemans, H.C.; Hoster, E.; Hermine, O.; Walewski, J.; Trneny, M.; Geisler, C.H.; Stilgenbauer, S.; Thieblemont, C.; Vehling-Kaiser, U.; Doorduijn, J.K.; et al. Treatment of older patients with mantle-cell lymphoma. N. Engl. J. Med. 2012, 367, 520-531. [CrossRef] [PubMed]

6. Dreyling, M.; Ferrero, S. The role of targeted treatment in mantle cell lymphoma: Is transplant dead or alive? Haematologica 2016, 101, 104-114. [CrossRef] [PubMed]

7. Cheah, C.Y.; Seymour, J.F.; Wang, M.L. Mantle cell lymphoma. J. Clin. Oncol. 2016, 34, 1256-1269. [CrossRef] [PubMed] 
8. Delarue, R.; Haioun, C.; Ribrag, V.; Brice, P.; Delmer, A.; Tilly, H.; Salles, G.; Van Hoof, A.; Casasnovas, O.; Brousse, N.; et al. Chop and DHAP plus rituximab followed by autologous stem cell transplantation in mantle cell lymphoma: A phase 2 study from the groupe d'etude des lymphomes de l'adulte. Blood 2013, 121, 48-53. [CrossRef] [PubMed]

9. Geisler, C.H.; Kolstad, A.; Laurell, A.; Jerkeman, M.; Raty, R.; Andersen, N.S.; Pedersen, L.B.; Eriksson, M.; Nordstrom, M.; Kimby, E.; et al. Nordic MCL2 trial update: Six-year follow-up after intensive immunochemotherapy for untreated mantle cell lymphoma followed by beam or beac + autologous stem-cell support: Still very long survival but late relapses do occur. Br. J. Haematol. 2012, 158, 355-362. [CrossRef]

10. Kolstad, A.; Laurell, A.; Jerkeman, M.; Gronbaek, K.; Elonen, E.; Raty, R.; Pedersen, L.B.; Loft, A.; Bogsrud, T.V.; Kimby, E.; et al. Nordic MCL3 study: 90y-ibritumomab-tiuxetan added to beam/c in non-cr patients before transplant in mantle cell lymphoma. Blood 2014, 123, 2953-2959. [CrossRef] [PubMed]

11. Andersen, N.S.; Pedersen, L.; Elonen, E.; Johnson, A.; Kolstad, A.; Franssila, K.; Langholm, R.; Ralfkiaer, E.; Akerman, M.; Eriksson, M.; et al. Primary treatment with autologous stem cell transplantation in mantle cell lymphoma: Outcome related to remission pretransplant. Eur. J. Haematol. 2003, 71, 73-80. [CrossRef]

12. Dreyling, M.; Lenz, G.; Hoster, E.; Van Hoof, A.; Gisselbrecht, C.; Schmits, R.; Metzner, B.; Truemper, L.; Reiser, M.; Steinhauer, H.; et al. Early consolidation by myeloablative radiochemotherapy followed by autologous stem cell transplantation in first remission significantly prolongs progression-free survival in mantle-cell lymphoma: Results of a prospective randomized trial of the european mcl network. Blood 2005, 105, 2677-2684. [PubMed]

13. Hoster, E.; Pott, C. Minimal residual disease in mantle cell lymphoma: Insights into biology and impact on treatment. Hematol. Am. Soc. Hematol. Educ. Program 2016, 2016, 437-445. [CrossRef] [PubMed]

14. Cowan, A.J.; Stevenson, P.A.; Cassaday, R.D.; Graf, S.A.; Fromm, J.R.; Wu, D.; Holmberg, L.A.; Till, B.G.; Chauncey, T.R.; Smith, S.D.; et al. Pretransplantation minimal residual disease predicts survival in patients with mantle cell lymphoma undergoing autologous stem cell transplantation in complete remission. Biol. Blood Marrow Transplant. 2016, 22, 380-385. [CrossRef] [PubMed]

15. Liu, H.; Johnson, J.L.; Koval, G.; Malnassy, G.; Sher, D.; Damon, L.E.; Hsi, E.D.; Bucci, D.M.; Linker, C.A.; Cheson, B.D.; et al. Detection of minimal residual disease following induction immunochemotherapy predicts progression free survival in mantle cell lymphoma: Final results of calgb 59909. Haematologica 2012, 97, 579-585. [CrossRef] [PubMed]

16. Pott, C. Minimal residual disease detection in mantle cell lymphoma: Technical aspects and clinical relevance. Seminars Hematol. 2011, 48, 172-184. [CrossRef] [PubMed]

17. Ladetto, M.; Magni, M.; Pagliano, G.; De Marco, F.; Drandi, D.; Ricca, I.; Astolfi, M.; Matteucci, P.; Guidetti, A.; Mantoan, B.; et al. Rituximab induces effective clearance of minimal residual disease in molecular relapses of mantle cell lymphoma. Biol. Blood Marrow Transplant. 2006, 12, 1270-1276. [CrossRef] [PubMed]

18. Andersen, N.S.; Pedersen, L.B.; Laurell, A.; Elonen, E.; Kolstad, A.; Boesen, A.M.; Pedersen, L.M.; Lauritzsen, G.F.; Ekanger, R.; Nilsson-Ehle, H.; et al. Pre-emptive treatment with rituximab of molecular relapse after autologous stem cell transplantation in mantle cell lymphoma. J. Clin. Oncol. 2009, 27, 4365-4370. [CrossRef] [PubMed]

19. Salles, G.; Seymour, J.F.; Offner, F.; Lopez-Guillermo, A.; Belada, D.; Xerri, L.; Feugier, P.; Bouabdallah, R.; Catalano, J.V.; Brice, P.; et al. Rituximab maintenance for 2 years in patients with high tumour burden follicular lymphoma responding to rituximab plus chemotherapy (prima): A phase 3, randomised controlled trial. Lancet 2011, 377, 42-51. [CrossRef]

20. Kahl, B.S.; Hong, F.; Williams, M.E.; Gascoyne, R.D.; Wagner, L.I.; Krauss, J.C.; Habermann, T.M.; Swinnen, L.J.; Schuster, S.J.; Peterson, C.G.; et al. Rituximab extended schedule or re-treatment trial for low-tumor burden follicular lymphoma: Eastern cooperative oncology group protocol e4402. J. Clin. Oncol. 2014, 32, 3096-3102. [CrossRef] [PubMed]

21. Kahl, B.S.; Longo, W.L.; Eickhoff, J.C.; Zehnder, J.; Jones, C.; Blank, J.; McFarland, T.; Bottner, W.; Rezazedeh, H.; Werndli, J.; et al. Maintenance rituximab following induction chemoimmunotherapy may prolong progression-free survival in mantle cell lymphoma: A pilot study from the wisconsin oncology network. Ann. Oncol. 2006, 17, 1418-1423. [CrossRef] [PubMed] 
22. Till, B.G.; Li, H.; Bernstein, S.H.; Fisher, R.I.; Burack, W.R.; Rimsza, L.M.; Floyd, J.D.; DaSilva, M.A.; Moore, D.F., Jr.; Pozdnyakova, O.; et al. Phase II trial of r-chop plus bortezomib induction therapy followed by bortezomib maintenance for newly diagnosed mantle cell lymphoma: Swog s0601. Br. J. Haematol. 2016, 172, 208-218. [CrossRef] [PubMed]

23. Chang, J.E.; Li, H.; Smith, M.R.; Gascoyne, R.D.; Paietta, E.M.; Yang, D.T.; Advani, R.H.; Horning, S.J.; Kahl, B.S. Phase 2 study of vcr-cvad with maintenance rituximab for untreated mantle cell lymphoma: An eastern cooperative oncology group study (e1405). Blood 2014, 123, 1665-1673. [CrossRef] [PubMed]

24. Rummel, M.J.; Knauf, W.; Goerner, M.; Soeline, U.; Lange, E.; Hertenstein, B.; Eggert, J.; Schliesser, G.C.; Weide, R.; Blumenstengel, K.; et al. Two years rituximab maintenance vs. Observation after first-line treatment with bendamustine plus rituximab (b-r) in patients with mantle cell lymphoma: First results of a prospective, randomized, multicenter phase II study (a subgroup study of the stil nhl7-2008 maintain trial). J. Clin. Oncol. 2016, 34, 7503.

25. Lenz, G.; Dreyling, M.; Hoster, E.; Wormann, B.; Duhrsen, U.; Metzner, B.; Eimermacher, H.; Neubauer, A.; Wandt, H.; Steinhauer, H.; et al. Immunochemotherapy with rituximab and cyclophosphamide, doxorubicin, vincristine, and prednisone significantly improves response and time to treatment failure, but not long-term outcome in patients with previously untreated mantle cell lymphoma: Results of a prospective randomized trial of the german low grade lymphoma study group (glsg). J. Clin. Oncol. 2005, 23, 1984-1992. [PubMed]

26. Brugger, W.; Hirsch, J.; Grunebach, F.; Repp, R.; Brossart, P.; Vogel, W.; Kopp, H.G.; Manz, M.G.; Bitzer, M.; Schlimok, G.; et al. Rituximab consolidation after high-dose chemotherapy and autologous blood stem cell transplantation in follicular and mantle cell lymphoma: A prospective, multicenter phase II study. Ann. Oncol. 2004, 15, 1691-1698. [CrossRef]

27. Horwitz, S.M.; Negrin, R.S.; Blume, K.G.; Breslin, S.; Stuart, M.J.; Stockerl-Goldstein, K.E.; Johnston, L.J.; Wong, R.M.; Shizuru, J.A.; Horning, S.J. Rituximab as adjuvant to high-dose therapy and autologous hematopoietic cell transplantation for aggressive non-hodgkin lymphoma. Blood 2004, 103, 777-783. [CrossRef] [PubMed]

28. Mangel, J.; Buckstein, R.; Imrie, K.; Spaner, D.; Crump, M.; Tompkins, K.; Reis, M.; Perez-Ordonez, B.; Deodhare, S.; Romans, R.; et al. Immunotherapy with rituximab following high-dose therapy and autologous stem-cell transplantation for mantle cell lymphoma. Semin. Oncol. 2002, 29, 56-69. [CrossRef] [PubMed]

29. Dietrich, S.; Weidle, J.; Rieger, M.; Meissner, J.; Radujkovic, A.; Ho, A.D.; Dreger, P.; Witzens-Harig, M. Rituximab maintenance therapy after autologous stem cell transplantation prolongs progression-free survival in patients with mantle cell lymphoma. Leukemia 2014, 28, 708-709. [CrossRef] [PubMed]

30. Graf, S.A.; Stevenson, P.A.; Holmberg, L.A.; Till, B.G.; Press, O.W.; Chauncey, T.R.; Smith, S.D.; Philip, M.; Orozco, J.J.; Shustov, A.R.; et al. Maintenance rituximab after autologous stem cell transplantation in patients with mantle cell lymphoma. Ann. Oncol. 2015, 26, 2323-2328. [CrossRef] [PubMed]

31. Le Gouill, S.; Thieblemont, C.; Oberic, L.; Moreau, A.; Bouabdallah, K.; Gyan, E.; Damaj, G.; Ribrag, V.; Feugier, P.; Casasnovas, O.; et al. Rituximab maintenance after autologous stem cell transplantation prolongs survival in younger patients with mantle cell lymphoma: Final results of the randomized phase 3 lyma trial of the lysa/goelams group. Blood 2016, 128, 145.

32. Mondello, P.; Steiner, N.; Willenbacher, W.; Arrigo, C.; Cuzzocrea, S.; Pitini, V.; Mian, M. 90y-ibritumomab-tiuxetan consolidation therapy for advanced-stage mantle cell lymphoma after first-line autologous stem cell transplantation: Is it time for a step forward? Clin. Lymphoma Myeloma Leuk. 2016, 16, 82-88. [CrossRef] [PubMed]

33. Kaplan, L.D.; Jung, S.-H.; Stock, W.; Bartlett, N.L.; Pitcher, B.; Byrd, J.C.; Blum, K.A.; LaCasce, A.S.; Fulton, N.; Hsi, E.D.; et al. Bortezomib maintenance (bm) versus consolidation (bc) following aggressive immunochemotherapy and autologous stem cell transplant (asct) for untreated mantle cell lymphoma (mcl): Calgb (alliance) 50403. Blood 2015, 126, 337.

34. Casulo, C.; Maragulia, J.; Zelenetz, A.D. Incidence of hypogammaglobulinemia in patients receiving rituximab and the use of intravenous immunoglobulin for recurrent infections. Clin. Lymphoma Myeloma Leuk. 2013, 13, 106-111. [CrossRef] [PubMed]

35. Issa, N.C.; Baden, L.R. Current issues in vaccines for adult patients with hematologic malignancies. J. Natl. Compr. Cancer Netw. 2012, 10, 1447-1454. 
36. Chaudhry, M.; Cheson, B.D. What is the status of novel anti-CD20 antibodies for chronic lymphocytic leukemia and are they set to leave rituximab in the shadows? Expert Rev. Hematol. 2015, 8, 733-742. [CrossRef] [PubMed]

37. Hillmen, P.; Robak, T.; Janssens, A.; Babu, K.G.; Kloczko, J.; Grosicki, S.; Doubek, M.; Panagiotidis, P.; Kimby, E.; Schuh, A.; et al. Chlorambucil plus ofatumumab versus chlorambucil alone in previously untreated patients with chronic lymphocytic leukaemia (complement 1): A randomised, multicentre, open-label phase 3 trial. Lancet 2015, 385, 1873-1883. [CrossRef]

38. Cheson, B.D.; Trněný, M.; Bouabdallah, K.; Dueck, G.; Gribben, J.; Lugtenburg, P.J.; Press, O.; Salles, G.A.; Fingerle-Rowson, G.; Mattiello, F.; et al. Obinutuzumab plus bendamustine followed by obinutuzumab maintenance prolongs overall survival compared with bendamustine alone in patients with rituximab-refractory indolent non-hodgkin lymphoma: Updated results of the gadolin study. Blood 2016, 128, 615.

39. Marcus, R.E.; Davies, A.J.; Ando, K.; Klapper, W.; Opat, S.; Owen, C.J.; Phillips, E.H.; Sangha, R.; Schlag, R.; Seymour, J.F.; et al. Obinutuzumab-based induction and maintenance prolongs progression-free survival (pfs) in patients with previously untreated follicular lymphoma: Primary results of the randomized phase 3 gallium study. Blood 2016, 128, 6 .

40. Morschhauser, F.A.; Cartron, G.; Thieblemont, C.; Solal-Celigny, P.; Haioun, C.; Bouabdallah, R.; Feugier, P.; Bouabdallah, K.; Asikanius, E.; Lei, G.; et al. Obinutuzumab (ga101) monotherapy in relapsed/refractory diffuse large b-cell lymphoma or mantle-cell lymphoma: Results from the phase II gauguin study. J. Clin. Oncol. 2013, 31, 2912-2919. [CrossRef] [PubMed]

41. Furtado, M.; Dyer, M.J.; Johnson, R.; Berrow, M.; Rule, S. Ofatumumab monotherapy in relapsed/refractory mantle cell lymphoma-A phase II trial. Br. J. Haematol. 2014, 165, 575-578. [CrossRef] [PubMed]

42. Barth, M.J.; Mavis, C.; Czuczman, M.S.; Hernandez-Ilizaliturri, F.J. Ofatumumab exhibits enhanced in vitro and in vivo activity compared to rituximab in preclinical models of mantle cell lymphoma. Clin. Cancer Res. 2015, 21, 4391-4397. [CrossRef] [PubMed]

43. Heinrich, D.A.; Weinkauf, M.; Hutter, G.; Zimmermann, Y.; Jurinovic, V.; Hiddemann, W.; Dreyling, M. Differential regulation patterns of the anti-CD20 antibodies obinutuzumab and rituximab in mantle cell lymphoma. Br. J. Haematol. 2015, 168, 606-610. [CrossRef] [PubMed]

44. Gopal, A.K.; Rajendran, J.G.; Petersdorf, S.H.; Maloney, D.G.; Eary, J.F.; Wood, B.L.; Gooley, T.A.; Bush, S.A.; Durack, L.D.; Martin, P.J.; et al. High-dose chemo-radioimmunotherapy with autologous stem cell support for relapsed mantle cell lymphoma. Blood 2002, 99, 3158-3162. [CrossRef] [PubMed]

45. Cassaday, R.D.; Stevenson, P.A.; Gooley, T.A.; Chauncey, T.R.; Pagel, J.M.; Rajendran, J.; Till, B.G.; Philip, M.; Orozco, J.J.; Bensinger, W.I.; et al. High-dose CD20-targeted radioimmunotherapy-based autologous transplantation improves outcomes for persistent mantle cell lymphoma. Br. J. Haematol. 2015, 171, 788-797. [CrossRef] [PubMed]

46. Pham, L.V.; Tamayo, A.T.; Yoshimura, L.C.; Lo, P.; Ford, R.J. Inhibition of constitutive nf-kappa b activation in mantle cell lymphoma b cells leads to induction of cell cycle arrest and apoptosis. J. Immunol. 2003, 171, 88-95. [CrossRef] [PubMed]

47. Robak, T.; Huang, H.; Jin, J.; Zhu, J.; Liu, T.; Samoilova, O.; Pylypenko, H.; Verhoef, G.; Siritanaratkul, N.; Osmanov, E.; et al. Bortezomib-based therapy for newly diagnosed mantle-cell lymphoma. N. Engl. J. Med. 2015, 372, 944-953. [CrossRef] [PubMed]

48. Goy, A.; Younes, A.; McLaughlin, P.; Pro, B.; Romaguera, J.E.; Hagemeister, F.; Fayad, L.; Dang, N.H.; Samaniego, F.; Wang, M.; et al. Phase ii study of proteasome inhibitor bortezomib in relapsed or refractory b-cell non-hodgkin's lymphoma. J. Clin. Oncol. 2005, 23, 667-675. [CrossRef] [PubMed]

49. O'Connor, O.A.; Wright, J.; Moskowitz, C.; Muzzy, J.; MacGregor-Cortelli, B.; Stubblefield, M.; Straus, D.; Portlock, C.; Hamlin, P.; Choi, E.; et al. Phase II clinical experience with the novel proteasome inhibitor bortezomib in patients with indolent non-hodgkin's lymphoma and mantle cell lymphoma. J. Clin. Oncol. 2005, 23, 676-684. [CrossRef] [PubMed]

50. Damon, L.E.; Johnson, J.L.; Niedzwiecki, D.; Cheson, B.D.; Hurd, D.D.; Bartlett, N.L.; Lacasce, A.S.; Blum, K.A.; Byrd, J.C.; Kelly, M.; et al. Immunochemotherapy and autologous stem-cell transplantation for untreated patients with mantle-cell lymphoma: Calgb 59909. J. Clin. Oncol. 2009, 27, 6101-6108. [CrossRef] [PubMed]

51. Argyriou, A.A.; Cavaletti, G.; Bruna, J.; Kyritsis, A.P.; Kalofonos, H.P. Bortezomib-induced peripheral neurotoxicity: An update. Arch. Toxicol. 2014, 88, 1669-1679. [CrossRef] [PubMed] 
52. Zhang, L.; Pham, L.V.; Newberry, K.J.; Ou, Z.; Liang, R.; Qian, J.; Sun, L.; Blonska, M.; You, Y.; Yang, J.; et al. In vitro and in vivo therapeutic efficacy of carfilzomib in mantle cell lymphoma: Targeting the immunoproteasome. Mol. Cancer Ther. 2013, 12, 2494-2504. [CrossRef] [PubMed]

53. Saba, N.S.; Liu, D.; Herman, S.E.; Underbayev, C.; Tian, X.; Behrend, D.; Weniger, M.A.; Skarzynski, M.; Gyamfi, J.; Fontan, L.; et al. Pathogenic role of b-cell receptor signaling and canonical nf-kappab activation in mantle cell lymphoma. Blood 2016, 128, 82-92. [CrossRef] [PubMed]

54. Wang, M.L.; Rule, S.; Martin, P.; Goy, A.; Auer, R.; Kahl, B.S.; Jurczak, W.; Advani, R.H.; Romaguera, J.E.; Williams, M.E.; et al. Targeting btk with ibrutinib in relapsed or refractory mantle-cell lymphoma. N. Engl. J. Med. 2013, 369, 507-516. [CrossRef] [PubMed]

55. Ruella, M.; Soubeyran, P. Walking a tightrope: Clinical use of ibrutinib in mantle cell lymphoma in the elderly. Hematol. Am. Soc. Hematol. Educ. Program 2016, 2016, 432-436. [CrossRef] [PubMed]

56. Levade, M.; David, E.; Garcia, C.; Laurent, P.A.; Cadot, S.; Michallet, A.S.; Bordet, J.C.; Tam, C.; Sie, P.; Ysebaert, L.; et al. Ibrutinib treatment affects collagen and von willebrand factor-dependent platelet functions. Blood 2014, 124, 3991-3995. [CrossRef] [PubMed]

57. Goy, A.; Sinha, R.; Williams, M.E.; Kalayoglu Besisik, S.; Drach, J.; Ramchandren, R.; Zhang, L.; Cicero, S.; $\mathrm{Fu}, \mathrm{T}$.; Witzig, T.E. Single-agent lenalidomide in patients with mantle-cell lymphoma who relapsed or progressed after or were refractory to bortezomib: Phase ii mcl-001 (emerge) study. J. Clin. Oncol. 2013, 31, 3688-3695. [CrossRef] [PubMed]

58. Gribben, J.G.; Fowler, N.; Morschhauser, F. Mechanisms of action of lenalidomide in b-cell non-hodgkin lymphoma. J. Clin. Oncol. 2015, 33, 2803-2811. [CrossRef] [PubMed]

(C) 2017 by the authors. Licensee MDPI, Basel, Switzerland. This article is an open access article distributed under the terms and conditions of the Creative Commons Attribution (CC BY) license (http:/ / creativecommons.org/licenses/by/4.0/). 